\title{
The International Trans-Antarctic Scientific Expedition (ITASE): an overview
}

\author{
Paul Andrew MAYEWSKI, ${ }^{1}$ Massimo FREZZOTTI, ${ }^{2}$ Nancy BERTLER, ${ }^{3}$
} Tas VAN OMMEN, ${ }^{4}$ Gordon HAMILTON, ${ }^{1}$ Tim H. JACKA, ${ }^{4}$ Brian WELCH, ${ }^{5}$ Markus FREY, ${ }^{6}$ QIN Dahe, ${ }^{7}$ REN Jiawen, ${ }^{8}$ Jefferson SIMÕES, ${ }^{9}$ Michel FILY, ${ }^{10}$ Hans OERTER, ${ }^{11}$ Fumihiko NISHIO, ${ }^{12}$ Elisabeth ISAKSSON, ${ }^{13}$ Robert MULVANEY, ${ }^{14}$ Per HOLMUND, ${ }^{15}$ Volodya LIPENKOV, ${ }^{16}$ Ian GOODWIN ${ }^{17}$

\section{On behalf of colleagues from the 19 nations that participate in ITASE}

\author{
${ }^{1}$ Climate Change Institute, University of Maine, 303 Bryand Global Sciences Center, Orono, ME 04469-5790, USA \\ E-mail: paul.mayewski@maine.edu \\ ${ }^{2}$ ENEA, Progetto Clima, Centro Ricerche Casaccia, I-00060 S. Maria Galeria (Roma), Italy \\ ${ }^{3}$ Antarctic Research Centre, Victoria University of Wellington, PO Box 600, Wellington, New Zealand \\ ${ }^{4}$ Department of the Environment and Heritage, Australian Antarctic Division, and Antarctic Climate and Ecosystems CRC, \\ Private Bag 80, Hobart, Tasmania 7001, Australia \\ ${ }^{5}$ Department of Physics, St Olaf College, 1500 St Olaf Avenue, Northfield, MN 55057, USA \\ ${ }^{6}$ Department of Hydrology and Water Resources, PO Box 210011, The University of Arizona, Tucson, AZ 85271-0011, USA \\ ${ }^{7}$ China Meteorological Administration, 46 Zhongguancun South Avenue, Beijing 100081, China \\ ${ }^{8}$ Lanzhou Institute of Glaciology and Geocryology, Chinese Academy of Sciences, 260 Donggang West Road, \\ Lanzhou 730000, China \\ ${ }^{9}$ Núcleo de Pesquisas Antarticas e Climáticas, Universidade Federal do Rio Grande do Sul, Avenido Bento Gonçalves 9500, \\ 91.501-970 Porto Alegre, Brazil \\ ${ }^{10}$ Laboratoire de Glaciologie et Géophysique de l'Environnement (CNRS-UJF), 54 rue Molière, BP 96, \\ 38402 Saint-Martin-d'Hères Cedex, France \\ ${ }^{11}$ Alfred Wegener Institute for Polar and Marine Research, PO Box 120161, D-27515 Bremerhaven, Germany \\ ${ }^{12}$ Center for Environmental Remote Sensing, Chiba University, Chiba 263-8522, Japan \\ ${ }^{13}$ Norwegian Polar Institute, Norwegian Environmental Centre, NO-9005 Tromsø, Norway \\ ${ }^{14}$ British Antarctic Survey, Natural Environment Research Council, Madingley Road, Cambridge CB3 OET, UK \\ ${ }^{15}$ Department of Physical Geography, Stockholm University, SE-106 91 Stockholm, Sweden \\ ${ }^{16}$ Arctic and Antarctic Research Institute, 38 Beringa Street, 119226 St Petersburg, Russia \\ ${ }^{17}$ School of Environmental and Life Sciences, University of Newcastle, Callaghan, New South Wales 2038, Australia
}

\begin{abstract}
From its original formulation in 1990 the International Trans-Antarctic Scientific Expedition (ITASE) has had as its primary aim the collection and interpretation of a continent-wide array of environmental parameters assembled through the coordinated efforts of scientists from several nations. ITASE offers the ground-based opportunities of traditional-style traverse travel coupled with the modern technology of GPS, crevasse detecting radar, satellite communications and multidisciplinary research. By operating predominantly in the mode of an oversnow traverse, ITASE offers scientists the opportunity to experience the dynamic range of the Antarctic environment. ITASE also offers an important interactive venue for research similar to that afforded by oceanographic research vessels and large polar field camps, without the cost of the former or the lack of mobility of the latter. More importantly, the combination of disciplines represented by ITASE provides a unique, multidimensional (space and time) view of the ice sheet and its history. ITASE has now collected $>20000 \mathrm{~km}$ of snow radar, recovered more than 240 firn/ice cores (total length $7000 \mathrm{~m}$ ), remotely penetrated to $\sim 4000 \mathrm{~m}$ into the ice sheet, and sampled the atmosphere to heights of $>20 \mathrm{~km}$.
\end{abstract}

\section{INTRODUCTION}

The broad aim of the International Trans-Antarctic Scientific Expedition (ITASE) is to establish how the modern atmospheric environment (climate and atmospheric composition) is represented in the upper layers of the Antarctic ice sheet. Primary emphasis is placed on the last $\sim 200$ years of the record, although some ITASE records encompass the last 1000 years. A 200 year time period was chosen for study because it is relatively simple to recover many ice cores covering this interval using oversnow traverse logistics, and also to develop a spatial network of cores valuable in understanding geographically constrained differences in climate over Antarctica. Further, this time period covers the onset of major anthropogenic involvement in the atmosphere and the immediate pre-anthropogenic atmosphere.

ITASE was conceived in 1990 and endorsed by the Scientific Committee on Antarctic Research (SCAR) Working Group on Glaciology and approved by the XXII SCAR Delegates at Bariloche, Argentina, in 1992. ITASE was 
endorsed as a core program of SCAR-GLOCHANT (Global Change and the Antarctic) in 1996. It was formally approved and adopted by the IGBP PAGES (International GeosphereBiosphere Program Past Global Changes) as a core project within Focus II on Antarctic Paleoenvironments. It also forms a contribution to the IGBP International Global Atmospheric Chemistry (IGAC) core project under their focus on Polar Air Snow Chemistry (PASC). As of XXVII SCAR in Shanghai, China, in 2002, 19 nations are involved in ITASE (Argentina, Australia, Belgium, Brazil, Canada, China, France, Germany, India, Italy, Japan, Netherlands, New Zealand, Norway, Russia, South Korea, Sweden, United Kingdom, United States).

For details concerning national programs, the ITASE Science and Implementation Plan (Mayewski, 1996) and other ITASE information, refer to the SCAR Project Office maintained at the Climate Change Institute, University of Maine (http://www2.umaine.edu/itase/).

\section{BACKGROUND}

Antarctica plays a critical role in the dynamic linkages that couple the spatially and temporally complex components of the Earth system (atmosphere, biosphere, anthrosphere, hydrosphere, cryosphere, lithosphere and cosmogenic input). However, our knowledge of the functioning of Antarctica within the global system and the spatial and temporal complexity of Antarctic climate is poor, largely due to the limitations and the short period (typically 30-50 years) of observational and instrumental data on Antarctic climatic variables. Further, Antarctica exhibits significant regional contrasts, including decoupling of climate change on decadal scales between different parts of the continent. Large areas of the interior of the ice sheet are influenced by the continental temperature inversion, while other portions of the interior and the coastal regions are influenced by the incursion of cyclonic systems that circle the continent. As a consequence, these coastal regions are mainly connected with lower-tropospheric transport, whereas high-altitude regions in the interior are more likely influenced by vertical transport from the upper troposphere and stratosphere. As a result, the coastal regions experience higher climatic variability than regions in the interior. Further, high-frequency climatic changes impact both Antarctica and the surrounding Southern Ocean. Some may be related to the El NiñoSouthern Oscillation (ENSO) and other local- to regional- to global-scale climate features such as atmospheric blocking, sea-ice variations and volcanic-event-induced atmospheric shielding. Over time periods longer than the instrumental era, ice-core studies demonstrate that Antarctica experienced millennial- to decadal-scale climatic variability which is associated with significant changes in temperature, snow accumulation, wind-blown dust, sea-salt loading and methane composition.

ITASE is focused to address two key scientific objectives:

What is the spatial and temporal variability of Antarctic climate (e.g. extreme events, regional to global atmospheric phenomena, and snow accumulation variations) over the last 200-1000 years?

What are the environmental changes (e.g. sea-ice variation, ocean productivity, anthropogenic activity, volcanic activity) impacting Antarctica over the last 200-1000 years?
ITASE has, since its inception in 1990, sampled an extensive portion of the Antarctic ice sheet, including many of the proposed deep ice-core drilling sites and much of the topography and climate of the Antarctic ice sheet (Fig. 1). To date, ITASE research has resulted in the collection of more than 240 cores (for a total length of $\sim 7000 \mathrm{~m}$ ), greatly expanding the pre-ITASE ice-core inventory over Antarctica (Fig. 2), and $>20000 \mathrm{~km}$ of associated ground-penetrating radar (GPR) coverage. Several properties were identified as part of the original ITASE sampling program, notably: isotopes, major anions and cations, trace elements, hydrogen peroxide $\left(\mathrm{H}_{2} \mathrm{O}_{2}\right)$, formaldehyde $(\mathrm{HCHO})$, organic acids, $10 \mathrm{~m}$ temperatures, stratigraphy, and GPR-GPS (global positioning system). Additionally, traverses have provided opportunities for the installation of automatic weather stations, and the measurement of, for example, atmospheric chemistry, ice dielectric and ice-core microparticles plus the deployment of experiments valuable for ground truth in remote-sensing missions and geophysical measurements for crustal investigation (Ferracioli and others, 2001). In sum, ITASE has developed into a highly multi- and interdisciplinary activity (Fig. 3).

To fulfill its objectives, ITASE is producing local- to regional- to continental-scale maps of past climate and environment, elucidating transfer functions between atmosphere/snow/ice, providing observational data for climate models, and both utilizing and validating satellite and ground-based remote sensing.

\section{OVERVIEW OF ITASE RESULTS}

Although full-scale reconstructions of past climate over Antarctica have yet to be finalized, ITASE has pioneered calibration tools and reconstruction of climate indices and evidence for climate forcing using single sites through to multiple arrays of sites. Initial syntheses of combined ITASE and deep ice-core records demonstrate that inclusion of instrumentally calibrated ITASE ice-core records allows previously unavailable reconstruction of past regional- to continental-scale variability in atmospheric circulation and temperature (Mayewski and others, 2004). Emerging results demonstrate the utilization of ITASE records in testing meteorological re-analysis products. Connections are now noted between ITASE climate proxies and global-scale climate indices such as ENSO (Meyerson and others, 2002; Bertler and others, 2004) in addition to major atmospheric circulation features over the Southern Hemisphere such as the Amundsen Sea low, East Antarctic high and Antarctic Oscillation (Kreutz and others, 2000; Proposito and others, 2002; Souney and others, 2002; Goodwin and others, 2003b; Becagli and others, 2004; Ekaykin and others, 2004; Xiao and others, 2004; Kaspari and others, 2005; Yan and others, 2005; Shulmeister and others, 2006). Ice-core nitrate concentrations have been used to reconstruct regional climate patterns associated with high-pressure ridging over Wilkes Land, East Antarctica (Goodwin and others, 2003b). Large-scale calibrations between satellite-deduced surface temperature and ITASE ice-core proxies for temperature are also now available (Schneider and others, 2005). ITASE is developing proxies for sea ice, a critical component in the climate system, through studies of sulfur compounds such as sulfate and methanesulfonate (MSA) (Welch and others, 1993; Curran and others, 2003; Dixon and others, 2005). ENSO-sea-ice connections are 


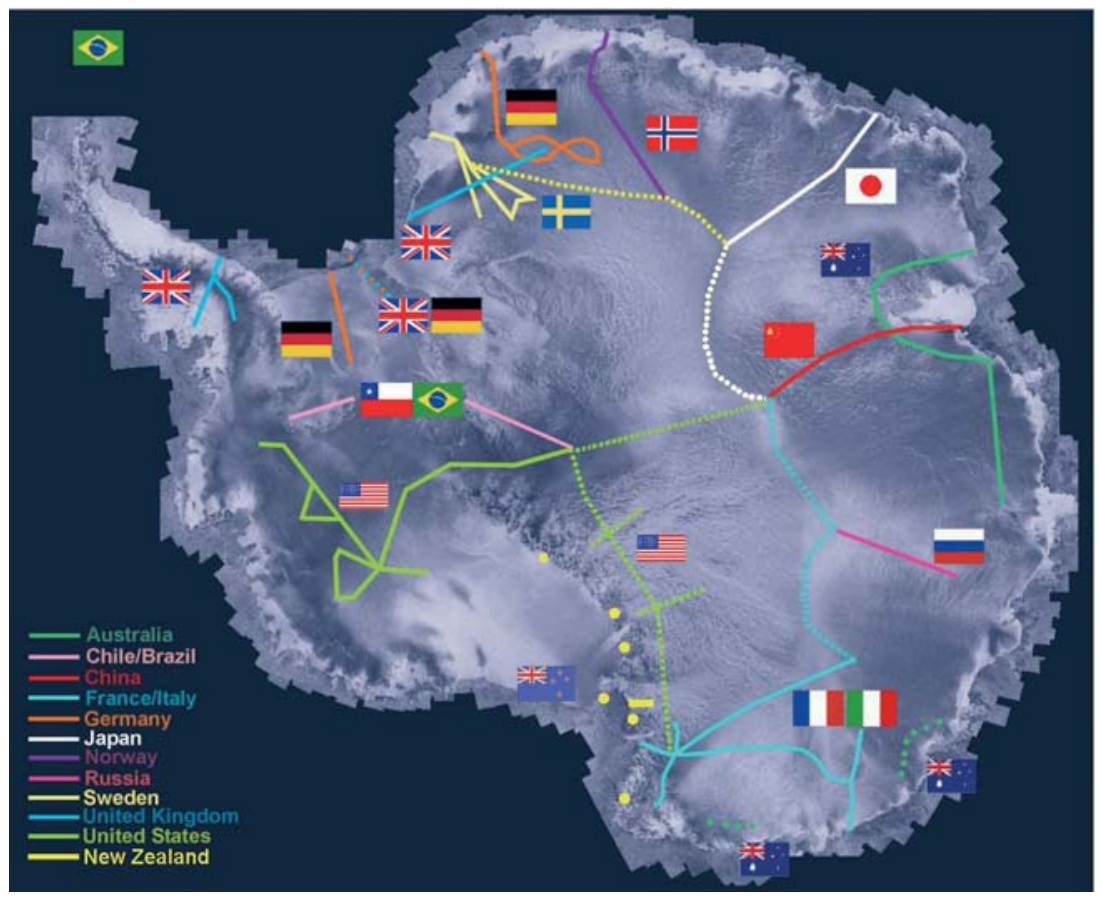

Fig. 1. ITASE traverse routes (completed (solid curves) and proposed (dashed curves)), superimposed on RADARSAT imagery (Jezek and others, 2002).

noted utilizing ice-core MSA and sulfate series over the Ross Sea embayment region (Meyerson and others, 2002; Becagli and others, 2005). Partitioning of the sources of sulfate is being undertaken through the examination of sulfur isotopes as an aid to further refining air-mass trajectory fingerprinting and the sulfur cycle over Antarctica (Pruett and others, 2004). ITASE research is also focused on understanding the factors that control climate variability over Antarctica and the Southern Ocean, through, for example, the documentation of the impact of solar forcing (via ultraviolet-induced changes in stratospheric ozone concentration) on zonal westerlies at the edge of the polar vortex (Van Ommen and Morgan, 2004; Mayewski and others, 2005).

The greatest unknown in the determination of the mass balance of the Antarctic ice sheet, and its potential role in sea level and ice dynamics, is the surface mass balance (snow accumulation which is precipitation minus sublimation and wind-blown snow). This is the input term in the ice-sheet mass-balance equation. Understanding the distribution of snow precipitation over the Antarctic continent, and the surface processes on different spatial and temporal scales (dependent on wind and surface slope) that redistribute that precipitation (Gow and Rowland, 1965; Whillans, 1975; Ekaykin and others, 2002; Frezzotti and others, 2002), is the area of greatest common interest between ITASE and another SCAR activity ISMASS (Ice Sheet Mass Balance and Sea Level program; see ISMASS Committee (2004) for a description of the rationale behind ISMASS and of areas of research in greatest need of attention). ITASE research reveals high variability in surface mass balance, and that single cores, stakes and snow pits do not represent the geographical and environmental characteristics of a local region (Richardson and Holmlund, 1999; Frezzotti and others, 2004b; Spikes and others, 2004). Field observations show that the interaction of surface wind and subtle variations of surface slope have a considerable impact on the spatial distribution of snow at short and long spatial scales (Van den Broeke and others, 1999; Albert, 2002) and that spatial variability of surface mass balance at the $\mathrm{km}$ scale is one order of magnitude higher than its temporal variability $(20-30 \%)$ at the centennial timescale (Frezzotti and others, 2004a). Data collected in the ITASE framework and by associated projects (EPICA DC (Dome Concordia) and DML (Dronning Maud Land), Siple Dome, Law Dome, Dome Fuji) also reveal systematic biases compared to previous compilations (Oerter and others, 1999; Frezzotti and others, 2004a; Magand and others, 2004; Rotschky and others, 2004).

The extensive use, along ITASE traverses, of new techniques like GPR and GPS, integrated with core data, provides detailed information on surface mass balance (Richardson and Holmlund, 1999; Urbini and others, 2001; Arcone and others, 2004; Rotschky and others, 2004). At many sites, stake-farm and ice-core accumulation rates are observed to differ significantly, but isochronal layers in firn, detected with GPR, correlate well with icecore chronologies (Frezzotti and others, 2004a). Some GPR layers have been surveyed extensively throughout Antarctica and they can be used as historical benchmarks to study past accumulation rates (V.B. Spikes and others, unpublished information). In addition, coupling ground survey data with satellite-based observations provides new tools for measuring, for example, ice surface velocity (Vittuari and others, 2004) and ice-sheet surface temperature (Schneider and Steig, 2002).

Atmosphere-snow chemical exchange processes play a key role in the quantitative interpretation (inversion) of icecore records (Wolff and Bales, 1996) as well as in tropospheric photochemistry of the polar latitudes (e.g. Dominé and Shepson, 2002; Jacobi and others, 2002). Century-scale records, from West Antarctica, of hydrogen peroxide, a potential proxy of past atmospheric oxidation 


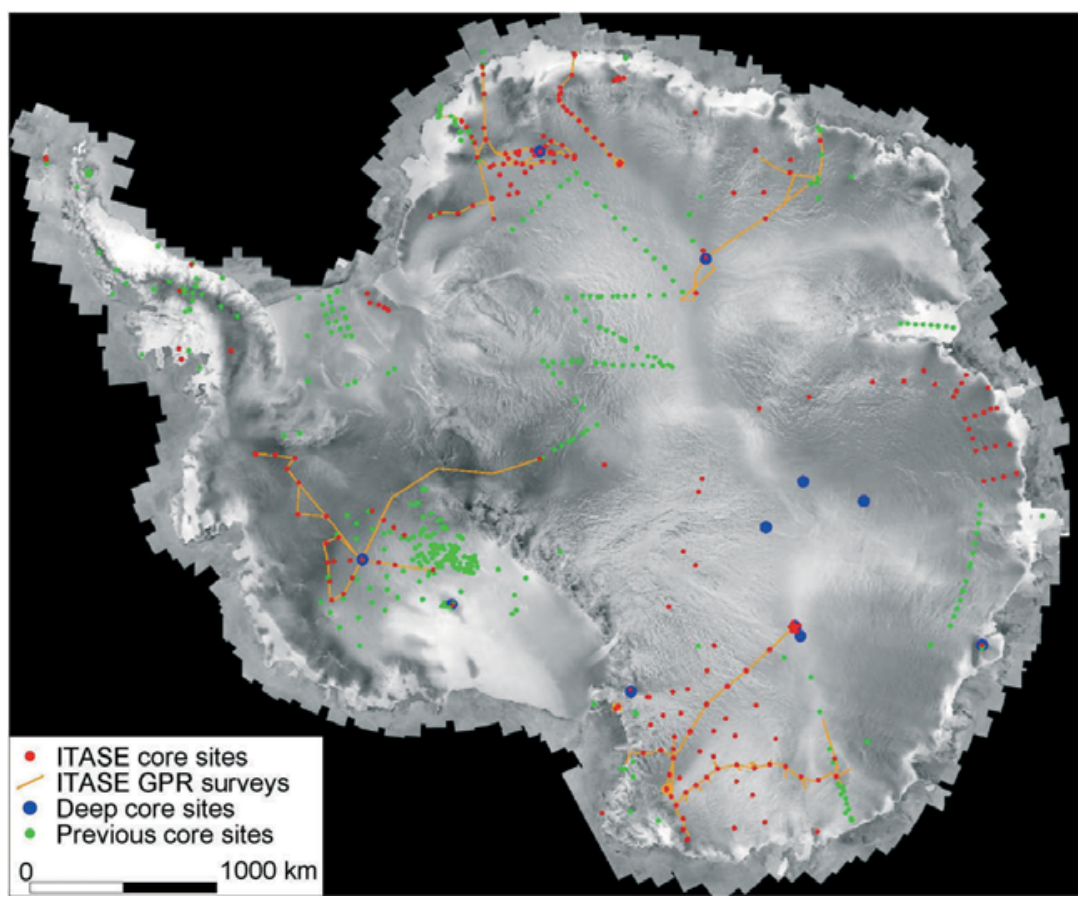

Fig. 2. ITASE core sites and shallow ITASE GPR surveys connecting sites plus previously recovered core sites and deep core sites, superimposed on the RADARSAT imagery (Jezek and others, 2002).

capacity, are reported from ITASE cores, and changes in firn concentrations are linked to trends in accumulation variability across large spatial scales (Frey and others, 2004). Continuous multi-day gas-phase measurements of peroxides, formaldehyde and ozone were conducted during three field seasons, for the first time on a ground traverse. Results include the first quantitative data from the interior of Antarctica of methylhydroperoxide (MHP), a higher organic peroxide acting as a radical reservoir, the detection of significant latitudinal gradients of atmospheric peroxides, as well as data on gaseous $\mathrm{HCHO}$ and $\mathrm{O}_{3}$ in a wide range of different depositional environments, such as up to a five-fold change in accumulation rate and a $30 \mathrm{~K}$ difference in mean annual temperature (Frey and others, 2003). Atmospheric measurements at ITASE sites are being compared to predictions of the NASA Goddard Space Flight Center (GSFC) point photochemical model and used, together with data from pit and core measurements, to validate existing atmosphere transfer models for $\mathrm{H}_{2} \mathrm{O}_{2}$ and $\mathrm{HCHO}$. On-site meteorology data and balloon soundings yielding vertical profiles of ozone, temperature and moisture provide further constraints in the ongoing modeling efforts of which the ultimate goal is a quantitative reconstruction of past change in atmospheric composition and oxidation potential.

Meteorological observations and ITASE field data coupled with mesoscale atmospheric model results (e.g. Van den Broeke, 1997; Gallée and others, 2001; Genthon and Krinner 2001) provide significant improvements to our understanding of post-depositional processes resulting from the interaction between surface layers of the atmosphere and snow (blowing snow and surface and blowing sublimation).

The growing ITASE database has the potential to explore temporal variability and recent evolution of Antarctic climate utilizing an unprecedented spatio-temporal array. Data extraction and validation activities are an essential preliminary (e.g. Steig and others, 2005) to the synthesis task. Such activities, together with development of instrumental calibration techniques, have been a significant component of ITASE studies. Maps of surface distribution of chemical species (Bertler and others, 2005) indicate the unprecedented scope for exploring climate variability as extended time series become available over broad regions through ITASE and deep drilling projects. An updated compilation of published and new data of major-ion and MSA concentrations from 522 Antarctic sites is provided by the national ITASE programs of Australia, Brazil, China, Germany, Italy, Japan, New Zealand, Norway, South Korea, the United Kingdom, the United States and the national Antarctic program of Finland. The concentrations of aerosol species vary by up to four orders of magnitude across Antarctica and exhibit distinct geographical patterns. The Antarctic-wide comparison of glaciochemical records provides a unique opportunity to achieve an understanding of the fundamental factors that ultimately control the chemistry of a snow or ice sample. The ability to determine individual sources and pathways of aerosols, as well as mechanisms that rule precipitation efficiency and post-depositional effects (Legrand and Mayewski, 1997), will allow exceptionally detailed and accurate interpretation of glaciochemical records, necessary for reconstructing past climate conditions with near-instrumental quality.

\section{CONCLUDING REMARKS}

Antarctica is Earth's largest storehouse of buried climate archives (ice cores) and ITASE has already changed this continent from the most poorly sampled of continents, with respect to climate, to the most highly resolved for periods extending beyond the instrumented record of climate. This remarkable accomplishment is essential to unraveling the role of Antarctica in the global climate system. Future ITASE traverses (Fig. 1) will be essential in completing this goal. 


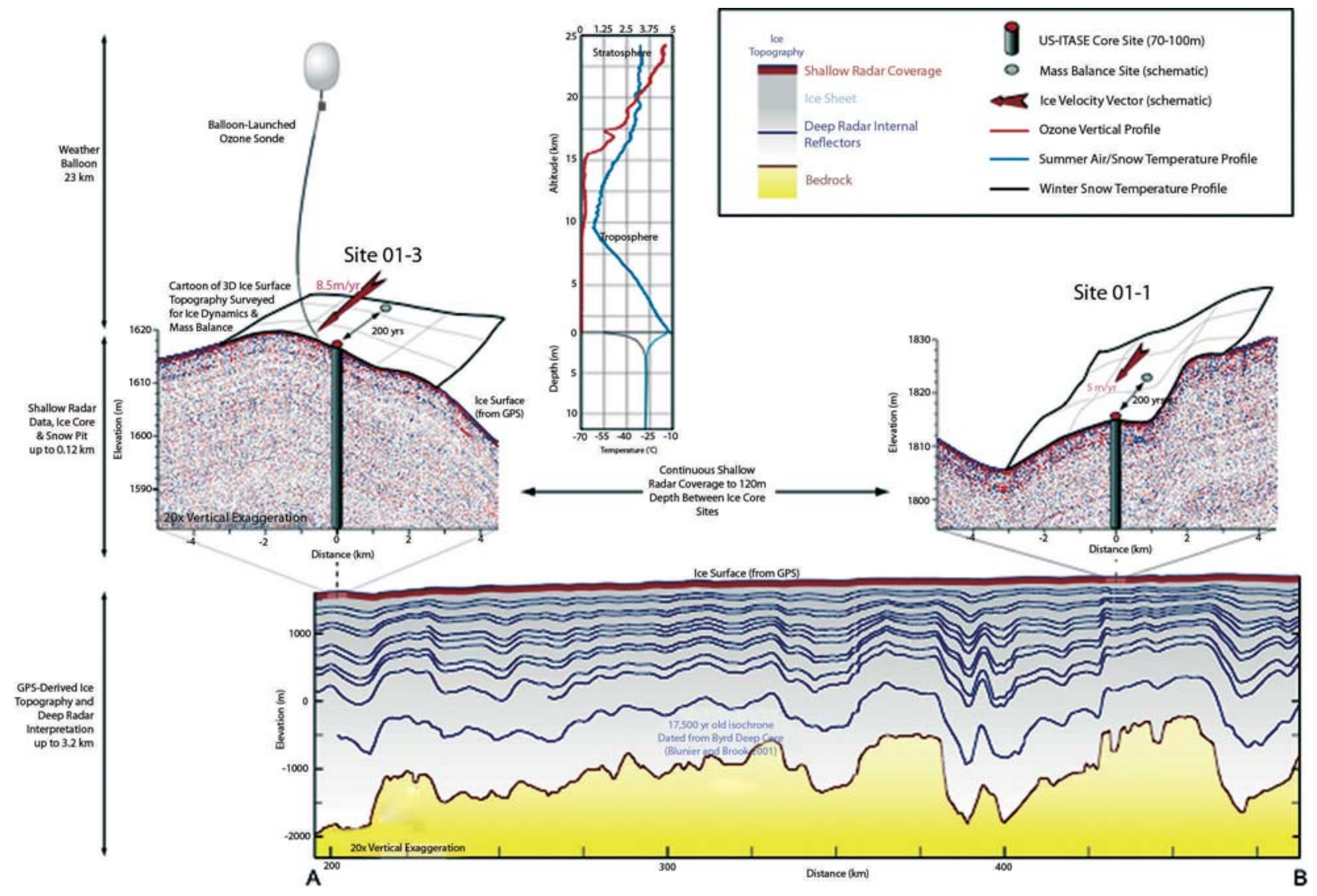

Fig. 3. Multidimensional approach to the multi- and interdisciplinary ITASE objectives. Studies at a variety of spatial scales extend from the subglacial bedrock surface to $>20 \mathrm{~km}$ into the atmosphere. Ice-core sites along traverse routes yield $\sim 200-1000$ year annually dated climate records at many sites. Ice-core site selection is determined by field interpretation of GPR. Numerous measurements are made at each site to provide context for ice-core records retrieved from sites. These measurements include, for example, high-resolution surface topography maps, snow-pit measurements of density, chemistry and temperature, plus meteorological data. For some traverses, ice mass-balance and horizontal velocity studies located $\sim 200$ years upflow provide past ice-flow history for the ice cores. Shallow- and deep-penetrating radioecho sounding data tie the ice cores together and provide large-scale context for ITASE cores and future deep ice-core climate records. Internal stratigraphy in GPR records represents isochronal events and a record of depositional and ice-flow history along the traverse. The radar data and interpretation, ozone sonde data, and ice topography along the radar profiles shown here are actual examples from the 2001 US ITASE season. Ice topography, mass-balance sites, and ice-velocity vectors are shown in schematic to represent results obtained once repeat analyses are completed.

\section{REFERENCES}

Albert, M.R. 2002. Effects of snow and firn ventilation on sublimation rates. Ann. Glaciol., 35, 52-56.

Arcone, S.A., V.B. Spikes, G.S. Hamilton and P.A. Mayewski. 2004. Stratigraphic continuity in 400-MHz short-pulse radar profiles of firn in West Antarctica. Ann. Glaciol., 39, 195-200.

Becagli, S. and 12 others. 2004. Chemical and isotopic snow variability in East Antarctica along the 2001/02 ITASE traverse. Ann. Glaciol., 39, 473-482.

Becagli, S. and 7 others. 2005. Relationship among SOI, sea ice extent and MSA concentration from Talos Dome ice cores. SCAR 28 Abstracts, 422.

Bertler, N.A.N., P.J. Barrett, P.A. Mayewski, R.L. Fogt, K.J. Kreutz and J. Shulmeister. 2004. El Niño suppresses Antarctic warming. Geophys. Res. Lett., 31(15), L15207. (10.1029/2004GL020749.)

Bertler, N.A.N. and 53 others. 2005. Snow chemistry across Antarctica. Ann. Glaciol., 41 (see paper in this volume).

Curran, M.A.J., T.D. van Ommen, V.I. Morgan, K.L. Phillips and A.S. Palmer. 2003. Ice core evidence for Antarctic sea ice decline since the 1950s. Science, 302(5648), 1203-1206.

Dixon, D. and 6 others. 2005. A 200 year sulfate record from 16 Antarctic ice cores and associations with Southern Ocean seaice extent. Ann. Glaciol., 41 (see paper in this volume).
Dominé, F. and P.B. Shepson. 2002. Air-snow interactions and atmospheric chemistry. Science, 297(5586), 1506-1510.

Ekaykin, A.A., V.Y. Lipenkov, N.I. Barkov, J.R. Petit and V. MassonDelmotte. 2002. Spatial and temporal variability in isotope composition of recent snow in the vicinity of Vostok station, Antarctica: implications for ice-core record interpretation. Ann. Glaciol., 35, 181-186.

Ekaykin, A.A., V.Y. Lipenkov, I.N. Kuz'mina, J.R. Petit, V. MassonDelmotte and S.J. Johnsen. 2004. The changes in isotope composition and accumulation of snow at Vostok station over the past 200 years. Ann. Glaciol., 39, 569-575.

Ferraccioli, F. and 6 others. 2001. Rifted crust at the East Antarctic Craton margin: gravity and magnetic interpretation along a traverse across the Wilkes Subglacial Basin region. Earth Planet. Sci. Lett., 192, 407-421.

Frey, M.M., J.R. McConnell, M.A. Hutterli, D. Belle-Oudry and R.C. Bales. 2003. Hydrogen peroxide and formaldehyde in snow and the atmosphere in West Antarctica: implications for boundary layer photo-chemistry and interpretation of ice core records. Geophys. Res. Abstr., 5, 03165.

Frey, M.M., J.R. McConnell, E. Hanna and R.C. Bales. 2004. First high resolution, century-scale ice core records of hydrogen peroxide from West Antarctica: contribution of accumulation variability. SCAR 28 Abstracts, 424. 
Frezzotti, M., S. Gandolfi and S. Urbini. 2002. Snow megadunes in Antarctica: sedimentary structure and genesis. J. Geophys. Res., 107(D18), 1-12.

Frezzotti, M. and 12 others. 2004a. New estimations of precipitation and surface sublimation in East Antarctica from snow accumulation measurements. Climate Dyn., 23(7-8), 803-813.

Frezzotti, M. and 13 others. 2004b. Spatial and temporal variability of snow accumulation in East Antarctica from traverse data. J. Glaciol., 51(172), 113-124.

Gallée, H., G. Guyomarc'h and E. Brun. 2001. Impact of snowdrift on the Antarctic ice sheet surface mass balance: possible sensitivity to snow-surface properties. Bound.-Lay. Meteorol., 99(1), 1-19.

Genthon, C. and G. Krinner. 2001. The Antarctic surface mass balance and systematic biases in GCMs. J. Geophys. Res., 106(D18), 20,653-20,664.

Goodwin, I.D., T.D. van Ommen, M.A.J. Curran and P.A. Mayewski. 2003a. Mid latitude winter climate variability in the south Indian and south-west Pacific regions since 1300 AD from the Law Dome ice core record. Climate Dyn., 22, 783-794.

Goodwin, I., H. De Angelis, M. Pook and N.W. Young. 2003b. Snow accumulation variability in Wilkes Land, East Antarctica and the relationship to atmospheric ridging in the $130^{\circ}-170^{\circ} \mathrm{E}$ region since 1930. J. Geophys. Res., 108(D21), 4673. (10.1029/ 2002JD002995.)

Gow, A.J. and R. Rowland. 1965. On the relationship of snow accumulation to surface topography at "Byrd Station", Antarctica. J. Glaciol., 5(42), 843-847.

ISMASS Committee. 2004. Recommendations for the collection and synthesis of Antarctic ice sheet mass balance data. Global Planet. Change, 42(1-4), 1-15.

Jacobi, H.W. and 7 others. 2002. Measurements of hydrogen peroxide and formaldehyde exchange between the atmosphere and surface snow at Summit, Greenland. Atmos. Environ., 36(15-16), 2619-2628.

Jezek, K.C. and RAMP Product Team. 2002. RAMP AMM-1 SAR image mosaic of Antarctica. Fairbanks, AK, Alaska SAR Facility, in association with the National Snow and Ice Data Center, Boulder, CO.

Kaspari, S., P.A. Mayewski, D.A. Dixon, S.B. Sneed and M.J. Handley. 2005. Sources and transport pathways of marine aerosol species into West Antarctica. Ann. Glaciol., 41 (see paper in this volume).

Kreutz, K.J., P.A. Mayewski, I.I. Pittalwala, L.D. Meeker, M.S. Twickler and S.I. Whitlow. 2000. Sea level pressure variability in the Amundsen Sea region inferred from a West Antarctic glaciochemical record. J. Geophys. Res., 105(D3), 4047-4059.

Legrand, M. and P. Mayewski. 1997. Glaciochemistry of polar ice cores: a review. Rev. Geophys., 35(3), 219-243.

Liu, H., K.C. Jezek and B. Li. 2000. RADARSAT Antarctic Mapping Project digital elevation model. Boulder, CO, National Snow and Ice Data Center.

Magand, O., M. Frezzotti, M. Pourchet, B. Stenni, L. Genoni and M. Fily. 2004. Climate variability along latitudinal and longitudinal transects in East Antarctica. Ann. Glaciol., 39, 351-358.

Mayewski, P.A. 1996. US ITASE: science and implementation plan. Durham, $\mathrm{NH}$, University of New Hampshire.

Mayewski, P.A. and 10 others. 2004. A 700 year record of Southern Hemisphere extratropical climate variability. Ann. Glaciol., 39, 127-132.

Mayewski, P.A. and 11 others. 2005. Solar forcing of the polar atmosphere: data, mechanisms, and implications. Ann. Glaciol., 41 (see paper in this volume).

Meyerson, E.A., P.A. Mayewski, K.J. Kreutz, L.D. Meeker, S.I. Whitlow and M.S. Twickler. 2002. The polar expression of ENSO and sea-ice variability as recorded in a South Pole ice core. Ann. Glaciol., 35, 430-436.

Oerter, H., W. Graf, F. Wilhelms, A. Minikin and H. Miller. 1999. Accumulation studies on Amundsenisen, Dronning Maud Land, by means of tritium, dielectric profiling and stable-isotope measurements: first results from the 1995-96 and 1996-97 field seasons. Ann. Glaciol., 29, 1-9.

Proposito, M. and 9 others. 2002. Chemical and isotopic snow variability along the 1998 ITASE traverse from Terra Nova Bay to Dome C, East Antarctica. Ann. Glaciol., 35, 187-194.

Pruett, L.E., K.J. Kreutz, M. Wadleigh, P.A. Mayewski and A. Kurbatov. 2004. Sulfur isotopic measurements from a West Antarctic ice core: implications for sulfate source and transport. Ann. Glaciol., 39, 161-168.

Richardson, C. and P. Holmlund. 1999. Spatial variability at shallow snow-layer depths in central Dronning Maud Land, East Antarctica. Ann. Glaciol., 29, 10-16.

Rotschky, G., O. Eisen, F. Wilhelms, U. Nixdorf and H. Oerter. 2004. Spatial distribution of surface mass balance on Amundsenisen plateau, Antarctica, derived from ice-penetrating radar studies. Ann. Glaciol., 39, 265-270.

Schneider, D.P. and E.J. Steig. 2002. Spatial and temporal variability of Antarctic ice sheet microwave brightness temperatures. Geophys. Res. Lett., 29(20), 1964. (10.1029/2002GL015490.)

Schneider, D.P., E.J. Steig and T. van Ommen. 2005. Highresolution ice-core stable-isotopic records from Antarctica: towards interannual climate reconstruction. Ann. Glaciol., 41 (see paper in this volume).

Shulmeister, J. and 10 others. 2006. The Southern Hemisphere Westerlies in the Australasian sector: a synthesis. Quat. Int., 118-119, 23-53.

Souney, J.M., P. Mayewski, I. Goodwin, V.I. Morgan and T. van Ommen. 2002. A late Holocene climate record from Law Dome, East Antarctica. J. Geophys. Res., 107(D22), 46084617.

Spikes, V.B., G.S. Hamilton, S.A. Arcone, S. Kaspari and P. Mayewski. 2004. Variability in accumulation rates from GPR profiling on the West Antarctic plateau. Ann. Glaciol., 39, 238-244.

Steig, E.J. and 16 others. 2005. High-resolution ice cores from US ITASE (West Antarctica): development and validation of chronologies and determination of precision and accuracy. Ann. Glaciol., 41 (see paper in this volume).

Urbini, S., S. Gandolfi and L. Vittuari. 2001. GPR and GPS data integration: examples of application in Antarctica. Ann. Geofis., 44(4), 687-702.

Van den Broeke, M.R. 1997. The spatial and temporal variation of sublimation on Antarctica: results of a high-resolution GCM. J. Geophys. Res., 102(D25), 29,765-29,778.

Van den Broeke, M.R. and 6 others. 1999. Climate variables along a traverse line in Dronning Maud Land, East Antarctica. J. Glaciol., 45(150), 295-302.

Van Ommen, T.D. and V. Morgan. 2004. A glacial and high resolution Holocene climate record from Law Dome, Antarctica. SCAR 28 Abstracts, 212.

Vittuari, L. and 6 others. 2004. Space geodesy as a tool for measuring ice surface velocity in the Dome $\mathrm{C}$ region and along the ITASE traverse. Ann. Glaciol., 39, 402-408.

Welch, K.A., P.A. Mayewski and S.I. Whitlow. 1993. Methanesulfonic acid in coastal Antarctic snow related to sea ice extent. Geophys. Res. Lett., 20(6), 443-446.

Whillans, I.M. 1975. Effect of inversion winds on topographic detail and mass balance on inland ice sheets. J. Glaciol., 14(70), 85-90.

Wolff, E.W. and R.C. Bales. 1996. Chemical exchange between the atmosphere and polar snow. Berlin, etc., Springer-Verlag. (NATO ASI Series I: Global Environmental Change 43.)

Xiao, C., P.A. Mayewski, D. Qin, Z. Li, M. Zhang and Y. Yan. 2004. Sea level pressure variability over the southern Indian Ocean inferred from a glaciochemical record in Princess Elizabeth Land, east Antarctica. J. Geophys. Res., 109(D16), D16101. (10.1029/2003JD004065.)

Yan, Y., P.A. Mayewski, S. Kang and E. Meyserson. 2005. An icecore proxy for Antarctic circumpolar wind intensity. Ann. Glaciol., 41 (see paper in this volume). 